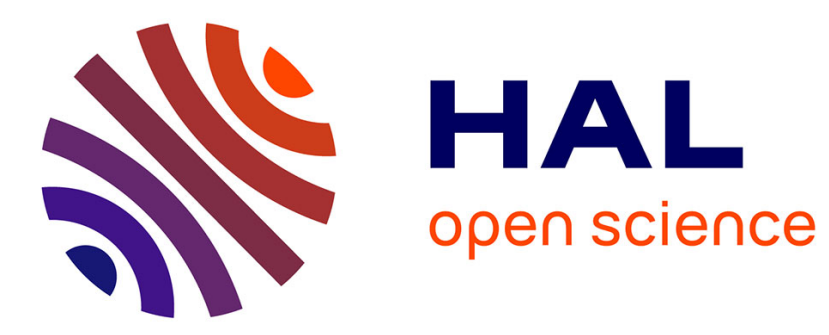

\title{
Relationships between climate and radial growth in black pine (Pinus nigra Arnold ssp. salzmannii (Dunal) Franco) from the south of France
}

\author{
Thomas Amodei, Frédéric Guibal, Bruno Fady
}

\section{- To cite this version:}

Thomas Amodei, Frédéric Guibal, Bruno Fady. Relationships between climate and radial growth in black pine (Pinus nigra Arnold ssp. salzmannii (Dunal) Franco) from the south of France. Annals of Forest Science, 2012, 70 (1), pp.41-47. 10.1007/s13595-012-0237-9 . hal-01201458

\author{
HAL Id: hal-01201458 \\ https://hal.science/hal-01201458
}

Submitted on 17 Sep 2015

HAL is a multi-disciplinary open access archive for the deposit and dissemination of scientific research documents, whether they are published or not. The documents may come from teaching and research institutions in France or abroad, or from public or private research centers.

$$
\text { Copyright }
$$

L'archive ouverte pluridisciplinaire HAL, est destinée au dépôt et à la diffusion de documents scientifiques de niveau recherche, publiés ou non, émanant des établissements d'enseignement et de recherche français ou étrangers, des laboratoires publics ou privés. 


\title{
Relationships between climate and radial growth in black pine (Pinus nigra Arnold ssp. salzmannii (Dunal) Franco) from the south of France
}

\author{
Thomas Amodei • Frédéric Guibal • Bruno Fady
}

Received: 11 April 2012 / Accepted: 9 August 2012 /Published online: 11 September 2012

(C) INRA / Springer-Verlag France 2012

\begin{abstract}
- Context The Salzmann pine (Pinus nigra ssp. salzmannii) is an endemic subspecies of black pine native to the Western Mediterranean basin. In Spain, Salzmann pine covers extensive areas (approx. 350000 ha), while in France where few scattered populations subsist, its distribution area is estimated at approx. 3000 ha.

- Method We used a dendroecological approach to understand the impact of climate fluctuations on Salzmann pine from France. Spatial and temporal variability of radial growth response was compared in three ecologically different populations (Conflent, Gorges du Tarn, Saint-Guilhem-le-Désert).

- Results The Conflent population showed a strong sensitivity to spring precipitation deficits (March to June), while at Gorges du Tarn and Saint-Guilhem sites, autumn (October) of the previous year and winter (February) temperatures explained more variance than precipitations and were, respectively, negatively and positively correlated to radial growth.
\end{abstract}

Handling Editor: Erwin Dreyer

Contribution of the co-authors Frédéric Guibal: fieldwork assistance, data analysis, supervising the work, and writing of paper Bruno Fady: sampling design, fieldwork assistance, supervising the work, and writing of paper

We submit this article within the framework of special MedPine4 conference (Avignon, 6-10 June 2011).

T. Amodei · F. Guibal $(\bowtie)$

Institut Méditerranéen de Biodiversité et d'Ecologie (IMBE), UMR CNRS 6116, Aix-Marseille Université,

Europôle méditerranéen de l'Arbois, Pavillon Villemin, BP 80,

13545 Aix en Provence Cedex 4, France

e-mail: frederic.guibal@imbe.fr

T. Amodei $\cdot$ B. Fady

INRA, UR629, Ecologie des Forêts Méditerranéennes(URFM),

Domaine Saint-Paul,

84914 Avignon Cedex 9, France
- Conclusion Although covering a limited distribution range in France, Salzmann pine demonstrated large differences in radial growth response to climate and soil variations.

Keywords Pinus nigra ssp. salzmannii · Tree ring · Climate $\cdot$ Soil $\cdot$ Response function $\cdot$ Dendroecology

\section{Introduction}

The Salzmann pine (Pinus nigra ssp. salzmannii) is an endemic subspecies of black pine native to the Western Mediterranean basin. In Spain, Salzmann pine covers extensive areas (approx. 350000 ha), while in France where few scattered populations subsist, its area is estimated at approx. 3000 ha. The restricted distribution of Salzmann pine in France is the relict of a much larger distribution area at the onset of the Quaternary period (Vernet et al. 2005). In addition to the successive interglacial episodes of the Quaternary, the current distribution of Salzmann pine is probably the result of strong anthropogenic activities (Calas 1900; Vernet 2006). Because of threats on their typical habitat (among which wildfires and hybridization with nonnative black pines are most prominent), Salzmann pine habitat is currently protected under the European Directive 92/43/ EEC (9530). As part of a nationwide conservation program, native individuals are being sampled and clonally propagated ex situ, while their genetic diversity is assessed. The results of the genetic study suggest that genetic differentiation between French stands is low but significant and their genetic diversity largest of all European black pine populations, except for the genetically depauperate populations from the isolated forest stands of Gorges du Tarn and Col d'Uglas (Fady et al. 2010).

For decades, the Salzmann pine has also been drawing some attention among forest managers because it is assumed 
to be relatively drought resistant and able to adapt to various soil types and climate conditions (Calas 1900; Quézel and Barbéro 1988; Costa et al. 1997). In that sense, the possibility to use Salzmann pine for plantation in the Mediterranean region is seriously considered although conservation issues have to be addressed in priority.

However, recent studies have pointed out that black pines are sensitive to summer drought (Génova and Fernández 1999; Lebourgeois 2000; Linares and Tiscar 2010). General circulation model simulations predict temperature increases and more frequent drought events at medium latitudes, particularly in the Mediterranean basin (Houghton 2011). Whereas a positive growth trend was shown by Corsican pines in western central France (Lebourgeois et al. 2000), a decreasing trend in radial increment is already observed in some black pine populations from the Western Mediterranean basin (Martin-Benito et al. 2010). In this context, to what extent Salzmann pines are sensitive to climate change and how they can be of use in declining black pine plantation forests are serious forest management questions.

Dendrochronology is a well-known and well-used method to understand how trees react to climate variations (Fritts 1976). Many studies focus on large-scale tree growth patterns while much fewer aim at assessing the long-term relationship between radial growth and climate at local site level. However, this type of study is necessary to understand which ecological factors drive the variability of radial growth response to climate variations within a species. In this study, our aims were threefold: (1) to further determine what are the climatic variables influencing radial growth of the French endemic populations of Salzmann pine, (2) to compare Salzmann pine radial growth response to climate variations in different stands, and (3) to assess the long-term variability of the radial growth response to climate throughout the twentieth century.

\section{Materials and methods}

\subsection{Study sites}

The study was carried out in three different forest sites within the native range of Salzmann pine in southern France: Saint-Guilhem-le-Désert (SG), Gorges du Tarn (GT), and Conflent valley (CO) (Fig. 1). Sites were chosen for their relative homogeneous topographic characteristics with steep slopes in the range of $15^{\circ}$ to $40^{\circ}$ and north-west aspect. The studied sites belong to the meso-Mediterranean climatic belt, and their elevation ranges between $587 \mathrm{~m}$ (SG) and $798 \mathrm{~m}(\mathrm{GT})$ above sea level. The soil texture is largely dominated by sand which generally produces well-drained soil subject to drought. Historical documents provided by the French National Forest Service indicate that in these formerly grazed areas turned to forests during the nineteenth century, the selected sites have remained unmanaged for the last 150 years. Table 1 summarizes topographic and climatic characteristics of the studied sites.

Conflent Mean annual precipitation is $646 \mathrm{~mm}$ (Tyndall climatic model, period 1961-1990). Mean annual temperature is $9.9{ }^{\circ} \mathrm{C}$, and temperature amplitude, around $10^{\circ} \mathrm{C}$, is stable along the year. Natural vegetation (Cistus laurifolius, Calluna vulgaris, Genista pilosa, etc.) indicates an acidic soil, and the bedrock is characterized by volcanic and gneissic rocks.

Gorges du Tarn The climatic influence of the Massif Central Mountain is pronounced in this site. Pines are growing on a dolomitic bed rock, on the steep slope of the Tarn river canyon. The oldest French Salzmann pine exceeding 450 years was described at this site. Annual precipitation is 1,060 mm (Tyndall climatic model, period 1961-1990). Mean annual temperature averages $11.2^{\circ} \mathrm{C}$, and seasons are characterized by a cold winter and hot summer.

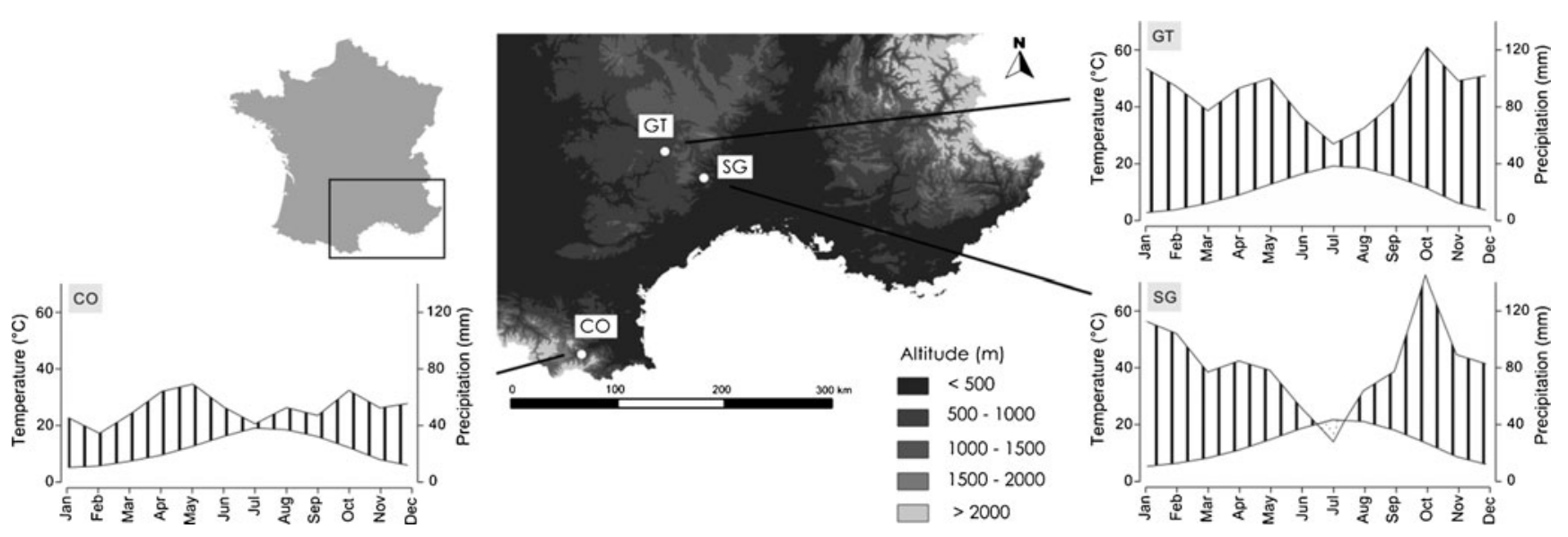

Fig. 1 Location of studied sites. Gaussen diagrams of each site are presented. Climatic data are calculated for the period 1961-1990. Bar plots represent the sum of monthly precipitations, and white-background plot, monthly temperatures. The intercept of two curves represents a dry period 
Table 1 Summary of site characteristics

Climatic data are calculated for the period 1961-1990. Values are means \pm standard deviation $S G$ Saint-Guilhem-le-Désert, $G T$ Gorges du Tarn, $C O$ Conflent, $T X$ monthly maximum temperatures, $T N$ monthly minimum temperatures, $P$ sum of annual precipitations

\begin{tabular}{|c|c|c|c|}
\hline Sites & SG & GT & $\mathrm{CO}$ \\
\hline Latitude (N) & $43^{\circ} 46^{\prime}$ & $44^{\circ} 17^{\prime}$ & $42^{\circ} 33^{\prime}$ \\
\hline Longitude (W) & $3^{\circ} 33^{\prime}$ & $3^{\circ} 17^{\prime}$ & $2^{\circ} 20^{\prime}$ \\
\hline Elevation (m) & $614 \pm 12$ & $728 \pm 33$ & $745 \pm 18$ \\
\hline Slope (deg) & $13 \pm 6$ & $42 \pm 4$ & $21 \pm 1$ \\
\hline Aspect & NO & $\mathrm{N}-\mathrm{NO}$ & NO \\
\hline Soil texture & Sand-silt & Sand-clay & Sand-silt \\
\hline Mean soil depth (mm) & 400 & 200 & 300 \\
\hline Tyndall grid references & 368,268 & 367,269 & 365,266 \\
\hline $\mathrm{TX}\left({ }^{\circ} \mathrm{C}\right)$ & 17.9 & 15.4 & 16.1 \\
\hline $\mathrm{TN}\left({ }^{\circ} \mathrm{C}\right)$ & 7.4 & 4.4 & 6.2 \\
\hline Total annual $P(\mathrm{~mm})$ & 998 & 1,060 & 646 \\
\hline
\end{tabular}

Saint-Guilhem-le-Désert This site is under Mediterranean climate with a pronounced summer drought particularly in July $(P<2$ Tm, Fig. 1). Mean annual precipitation is $998 \mathrm{~mm}$ (Tyndall climatic model, period 1961-1990) and mainly occurs during the autumn and winter periods. Mean annual temperature is $12.7^{\circ} \mathrm{C}$. Natural vegetation (Quercus ilex, Buxus sempervirens, Sorbus aria, etc.) indicates a neutral soil and, as in the Gorges du Tarn, the bedrock is dolomitic.

\subsection{Meteorological data}

For estimating ring width to climate relationships, we selected monthly variables potentially able to limit radial growth (Fritts 1976). Monthly maximum and minimum temperatures (respectively, TX and TN) and monthly precipitations $(P)$ were collected from the Tyndall climatic model $\left(0.5^{\circ} \times 0.5^{\circ}\right.$ grid box $)$ elaborated by Mitchell et al. (2002). This model presents the advantage to provide climatic data from 1901 to 2002 while meteorological records from the French National Meteorological Agency (MeteoFrance) often start after 1950. To check the conformity of modeled data with local climate of each site, we used a linear regression between the Tyndall and measured data at the three closest meteorological stations from each site: the linear regressions showed significant regression coefficient $(p<0.01)$ ranging between 0.56 and 1.06 for precipitation and between 0.88 and 1.01 for temperature. Mann-Kendall tests were applied to underline possible trends over time between both types of data. The Mann-Kendall test indicated a strong agreement between Tyndall data and climatic records from MeteoFrance at all sites. Kendall tau ranged between 0.86 and 0.89 for TX and TN. Precipitation presented less conformity as shown by the tau which ranged between 0.42 and 0.51 . The Tyndall data generally underestimated the annual precipitations by 100 to $260 \mathrm{~mm}$.

\subsection{Tree ring data and dendroecological methods}

Measurement At each site, we selected 20 trees among dominant and healthy pines and bored one core per tree from the base of the trunk using a Swedish increment borer. All cores were sanded and cross-dated, and tree-ring widths were measured to the nearest $1 / 100 \mathrm{~mm}$ using a LINTAB6 measuring table and the TSAP software (Rinntech $\left.{ }^{\circledR}\right)$. Crossdating was checked by using the COFECHA software (Holmes 1983).

Standardization To remove low frequency variations linked to tree aging, tree-ring widths were converted into a standard index using the filtering method developed in the 3 pBase software (Guiot and Gœury 1996). A 10-year filtering window was adapted to enhance high-frequency signal and to fit a function to measured chronologies. Mean sensitivity and first-order autocorrelation (AC) were calculated to assess, respectively, the year-to-year variations and the influence of previous year's width on current year width.

Response functions The relationship between standardized chronologies and climatic data was analyzed by means of response functions (Fritts 1976). The 3pBase program (Guiot and Gœury 1996) and its bootstrap method (Guiot 1991) were used for the analyses. We used 14 monthly climatic variables as regressors, starting in October of previous year $(t-1)$ to September of current year $(t)$. We chose this calendar (Oct $t-1$ to Sept $t$ ) to better take into account the physiological cycle of trees. The mean standardized chronologies were used as dependent variables in the models.

First, we calculated the response function for the whole period 1901-2002. Then, to assess the long-term variability of the relationship between tree ring and climate during the twentieth century, we used the DENDROCLIM2002 program (Biondi and Waikul 2004) to calculate moving 
response functions. Moving response functions are based on shifting the period of a fixed number of years through time to compute the response coefficients. The moving response functions were calculated for a 30 -year period, moving along the whole chronology. This 30 -year window is long enough to avoid biases induced by extreme events and short enough to retain the influence of midfrequency climate variations on growth. Results of response functions are presented as a ratio, usually called correlation/regression coefficient, between the regression coefficient of each monthly variable and the associated standard deviation. This ratio is significant at $95 \%$ when higher, in absolute value, than 1.96. This coefficient provides the intensity of the relationship between radial growth and climate, taking into account the uncertainty of the model (Guiot and Nicault 2010).

\section{Results}

\subsection{Analysis of climate data}

An increasing linear trend in annual maximum and minimum temperatures was clearly observed during the period 1901-2002 at all sites. The greater increase was observed at the southern site $(\mathrm{CO})$ with $0.013{ }^{\circ} \mathrm{Cyear}^{-1}\left(r^{2}=0.32, p=\right.$ $0.0001)$ and the smaller one at the northern site (GT) with $0.011{ }^{\circ}$ Cyear $^{-1}\left(r^{2}=0.19, p=0.0001\right)$. The trends were particularly strong during summer and early autumn seasons (July, $+0.015^{\circ} \mathrm{Cyear}^{-1}$; August, $+0.020^{\circ} \mathrm{C}^{\circ} \mathrm{ear}^{-1}$; September, $+0.014{ }^{\circ} \mathrm{Cyear}^{-1}$; October, $+0.019^{\circ} \mathrm{Cyear}^{-1}$ ). No significant trends were observed for precipitations during the period 1901-2002.

\subsection{Chronology statistics}

The chronologies spanned 130 to 316 years. The three mean site chronologies shared a common period (depth size: 20 samples measured per site) from 1878 to 2007. Probably because SG is an older population, the annual radial growth appeared to be twice as thin at that site than at both other sites (Table 2). Mean sensitivity, calculated on raw data, ranged from 0.26 to 0.38 . The higher value, observed on the southernmost site (CO), indicated a homogenous and pronounced response of Salzmann pines to interannual climate variations. The first-order autocorrelation coefficients, calculated on raw data, were relatively homogenous from one site to another and varied from 0.74 to 0.77 , emphasizing the high interannual correlation between tree-ring widths. When calculating first-order autocorrelation coefficients on standardized indices, values reached 0.10 and never exceeded 0.19 indicating that a small amount of low-frequency year-to-year variation remained in the
Table 2 Number of trees and dendrochronological characteristics of Pinus nigra ssp. salzmannii populations at studied sites

\begin{tabular}{lcccc}
\hline Sites & SG & GT & CO \\
\hline Number of trees & & 20 & 19 & 21 \\
Age (in 2011) & Min & 159 & 130 & 134 \\
& Max & 316 & 457 & 166 \\
& Mean & 247 & 195 & 156 \\
Total height (m) & & 15 & 15 & 12 \\
Diameter (cm) & $28.9 \pm 6.3$ & $32.8 \pm 8.2$ & $30.3 \pm 7.1$ \\
Mean sensitivity & 0.28 & 0.26 & 0.38 \\
AC before std. & 0.75 & 0.77 & 0.74 \\
AC after std. & 0.19 & 0.15 & 0.01 \\
\hline
\end{tabular}

Mean sensitivity is calculated on raw data for each tree and averaged per site. Values are means \pm standard deviation

$A C$ before std. first-order autocorrelation before standardization, $A C$ after std. first-order autocorrelation after standardization

standardized tree-ring chronologies. Table 2 sums up tree and dendrochronological characteristics at all sites.

\subsection{Radial growth and climate relationship}

In response functions, the amount of variance explained by the model $\left(r^{2}\right)$ for a given variable reflects its mean contribution to radial growth. At the dryer site $(\mathrm{CO})$, precipitations explained more variance $\left(r^{2}=0.54\right)$ than temperatures $\left(r^{2}=0.41\right.$ and $r^{2}=0.43$, respectively, for the TX and TN models). On the contrary, at the other sites (GT and SG) which are wetter and warmer, temperatures explained more variance $\left(r^{2}=0.56\right)$ than precipitations $\left(r_{\mathrm{GT}}{ }^{2}=0.49\right.$ and $r_{\mathrm{SG}}^{2}=0.52$ ).

Differences between the dryer site (CO) and the wetter and warmer sites (GT and $\mathrm{SG}$ ) were clear and pronounced in the response function results (Fig. 2). Winter and spring precipitations (February, March, May, June) positively influenced radial growth at the southern and dryer site (CO). At northern and wetter sites (GT, SG), February temperatures positively influenced radial growth while October and November $t-1$ temperatures exerted opposite influences (negative with October and positive with November). May, June, and July maximum temperatures negatively influenced radial growth at the northern sites (GT, SG) but that influence was lower than that of autumn and winter.

\subsection{Temporal variations of the radial growth relationships}

Moving response functions (Fig. 3) underlined two types of relationships between radial growth and climate for the period 1930-2002: while some were roughly temporally stable, others appeared unstable throughout the period. At $\mathrm{SG}$, the positive correlation between growth and winter 

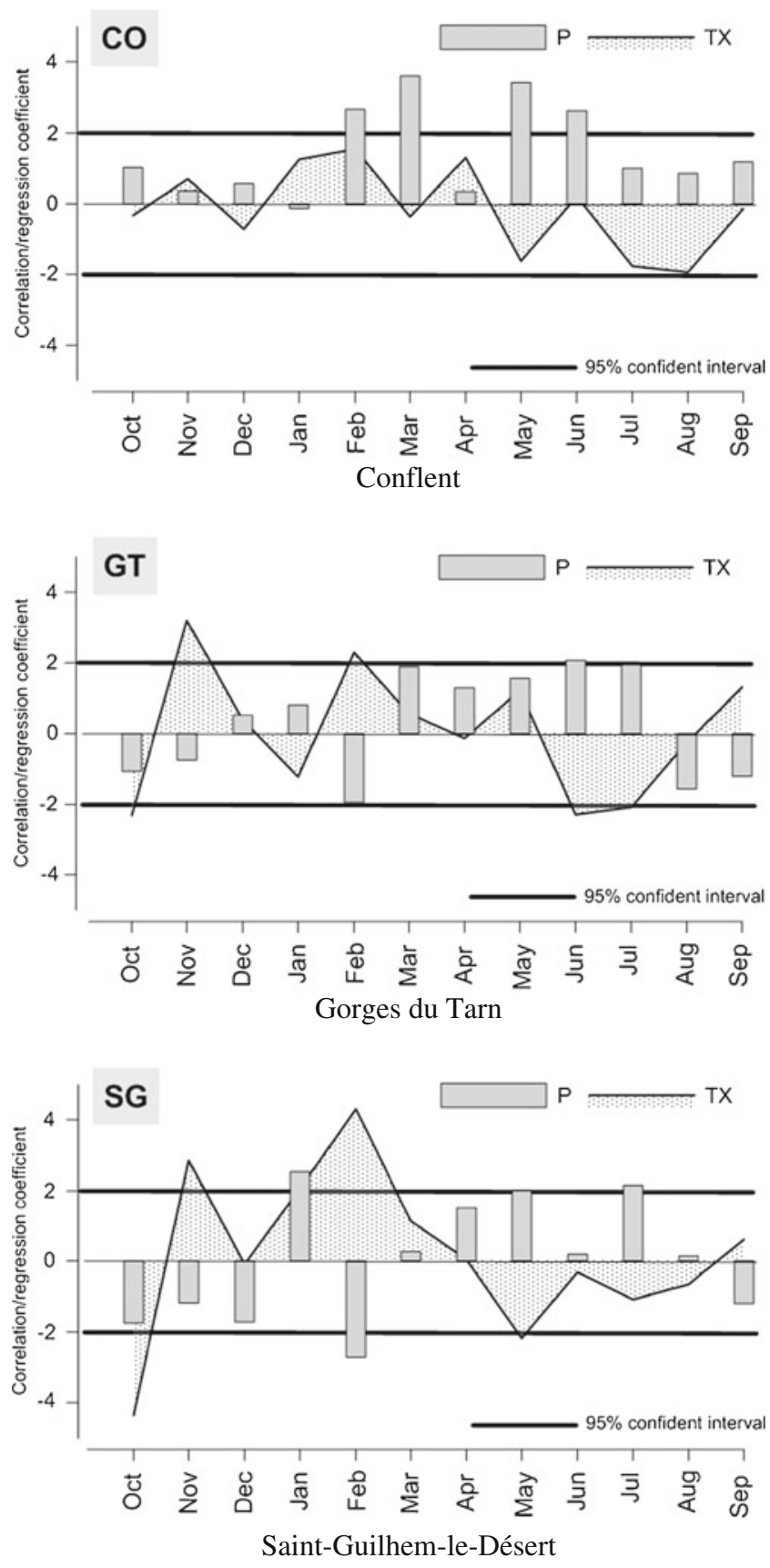

Fig. 2 Correlation/regression coefficients between monthly maximum temperatures $(T X)$ and monthly precipitations $(P)$ and standardized tree-ring chronologies at $\mathrm{CO}, \mathrm{GT}$, and SG. Above +2 bold line and under -2 bold line, coefficients are significant at a threshold of $95 \%$

temperatures (February) remained constant between 1955 and 2002. The positive correlation between November temperatures and radial growth at the northern sites (GT, SG) also appeared durable between 1930 and 2002. At CO, the positive correlation between spring precipitations and radial growth was relatively constant over time and varied from May to March. The influence of summer temperatures (June, July) showed a relative synchronic pattern at all sites.
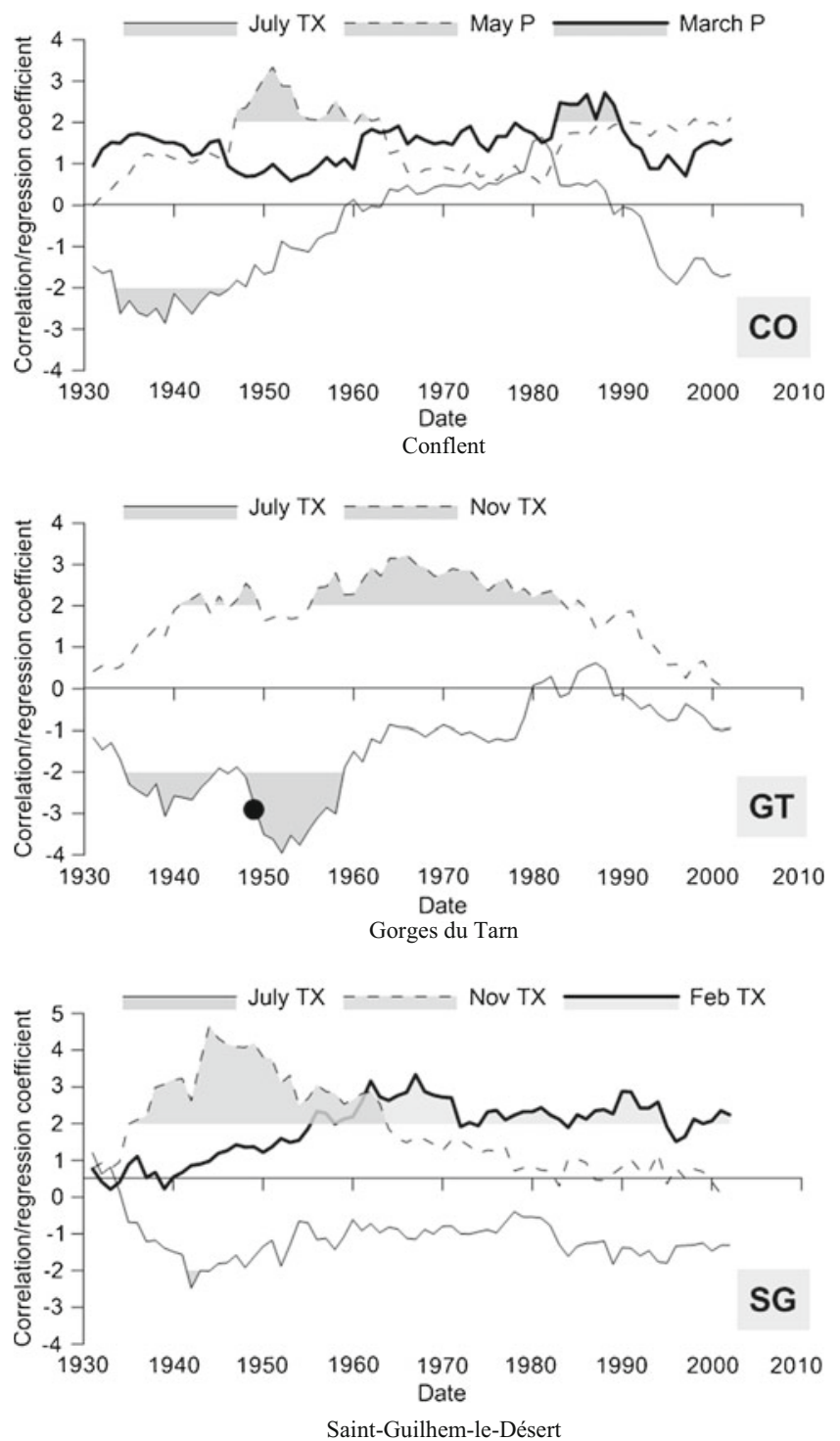

Fig. 3 Moving response functions (MRF) at CO, GT, and SG. Each value corresponds to the correlation/regression coefficient calculated on the 30 previous years. $T X$ monthly maximum temperatures, $P$ cumulus of monthly precipitations. Colored zones correspond to $95 \%$ significance coefficients. The black dot locates the 1949 wildfire at GT

The negative correlation with radial growth was no longer significant after the 1950-1960 period.

\section{Discussion}

Several studies have shown that black pine is sensitive to high summer temperatures and to water deficit during spring and summer (Martin-Benito et al. 2010; Lebourgeois 2000; Génova and Fernández 1999). The impact of climate change on radial growth, and particularly that of a dryer summer period, was recently demonstrated in Spain (Linares and 
Tiscar 2010; Martin-Benito et al. 2010). In the case of Salzmann pine, Génova and Martinez-Morillas (2002) also demonstrated that analyzing the correlation between radial growth response and climate should be modulated according to soil substrate characteristics. They pointed out the fact that, under the same regional climate conditions, Salzmann pines on quartzite bedrock were much more sensitive to summer precipitations, while on dolomitic and calcareous bedrock, pines were less dependent on precipitation.

We observed significant differences in radial growth response to climate variations among sites. The northern sites (GT, SG) showed similar radial growth responses: temperatures appeared as the predominant driver of radial growth. At the southern site (CO), the only significant climatic factor affecting radial growth was precipitations. The mean regional climate is clearly different between northern and southern sites and could partly explain such differences. Precipitations are two times lower at $\mathrm{CO}$ than at other sites. In addition, differences in radial growth response between sites could be interpreted in the context of the ecological differences between sites. At $\mathrm{CO}$, periods of water deficit at the onset of the vegetative period exacerbated by a particular compact gneissic bedrock could be a strong limiting factor for radial growth. In agreement with the results of Génova and Martinez-Morillas (2002), the observed differences between radial growth patterns of CO and GT-SG could also be related to soil texture and substrate conditions. On dolomitic and calcareous bedrock (GT, SG), the effect of chemical alteration of calcareous may offer the opportunity to pine roots to prospect deeper levels for water resource.

The negative effect of October $t-1$ temperatures on black pine radial growth has been reported in previous studies (Linares and Tiscar 2010; Martin-Benito et al. 2010; Génova and Fernández 1999). A growing season extending late into October $t^{-1}$ may have a strong influence on the current growing season. By maintaining a low rate of photosynthetic activity and respiration late in the season, it may reduce the quantity of carbohydrate resource available for the following year (Andreu et al. 2007; Génova and Fernández 1999; Fritts 1976).

The positive correlation between radial growth and February temperatures is mentioned by Linares and Tiscar (2010) at wetter sites in southern Spain. Higher temperatures in February lead to wider tree rings by promoting an early bud opening, which consequently increases the length of the growing season, as observed for species such as Pinus pinea (Campelo et al. 2007) and Quercus ilex (Campelo et al. 2009) in Portugal and Pinus pinaster in central Spain (Bogino and Bravo 2008). In agreement with these results, a February temperature effect is observed at wetter sites (GT, SG) and particularly in SG. Physiological studies have shown that January and February match with the dormancy breaking phase (Dereuddre and Gazeau 1992) during which a progressive decrease of cold hardiness occurs. We hypothesize that dormancy could decrease in February at SG which is the warmest studied site $\left(+2{ }^{\circ} \mathrm{C}\right.$ on average compared to other sites) and that after dormancy breaking, exceptionally low temperatures could strongly affect cambial cells and subsequent radial growth. In addition to that, low February temperatures could also affect winter photosynthesis as it has been reported for other conifers (Wieser 1997; Lebourgeois 2000).

Moving response functions are consistent with response functions obtained on the whole length of the chronologies and ascertain the temporal evolution of radial growth to climate relationships between 1901 and 2002. The strongest and long-term most stable climatic signal is a direct response of radial growth to spring precipitations at $\mathrm{CO}$, the driest site. Such a stable relationship could partly be related with invariant century scale factors such as soil or spring precipitation. The relationship between mean July temperatures and radial growth appears unstable over the period 1901-2002 and follows relatively similar patterns at all sites. When displaying mean July temperature long-term variation with correlation/regression coefficient in the same graph (Fig. 4), we can notice that when temperatures rise, the coefficient decreases (the negative effect of high July temperatures is more pronounced) and vice versa. In the year following 1980, while July temperatures rise above those of the $1950 \mathrm{~s}$, the correlation/regression coefficient decreases at all sites although it remains nonsignificant. This result suggests an increase in water stress effect due to higher temperatures during the last decades of the twentieth century. Similar changes in climatic response were observed

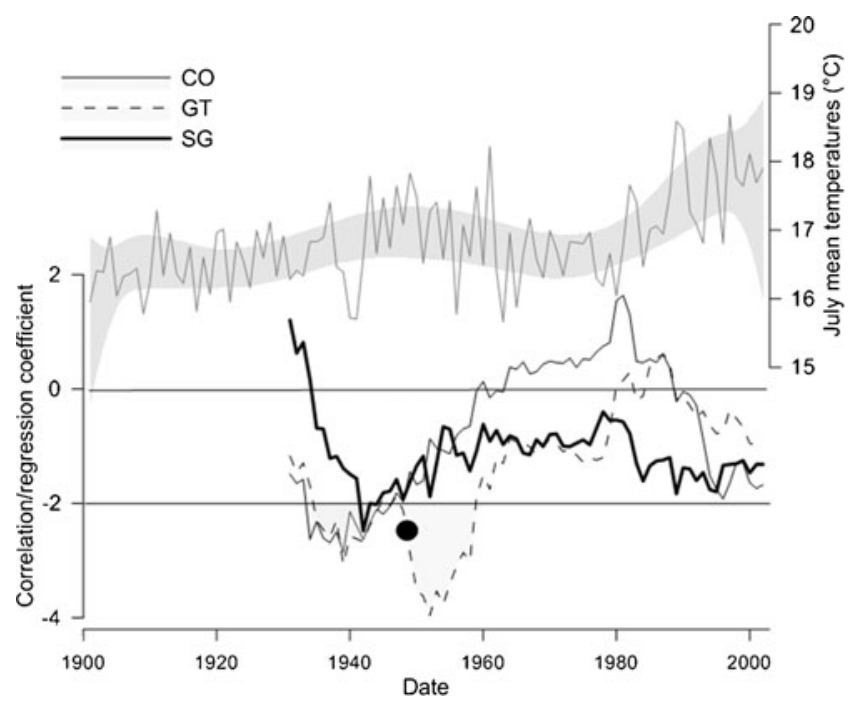

Fig. 4 Evolution of the July correlation/regression coefficient at CO, GT, and SG and July mean temperatures between 1901 and 2002. July temperatures are averages between the three sites. The gray plot represents a $95 \%$ confidence interval of a polynomial function fitted on July temperatures. The black dot locates the 1949 wildfire at GT. Under - 2 line, the correlation/regression coefficients are significant at a threshold of $95 \%$ 
between late summer temperatures prior to growth and radial growth in Pinus uncinata (Andreu et al. 2007). In a climate change context, July temperature increase could cause a decrease of the correlation/regression coefficient which could eventually reach significant values.

It must be emphasized that in 1949, a large wildfire partly devastated the GT Salzmann pine forest. The sharp decrease of the correlation/regression coefficient which occurred after this event indicates that the summer drought effect on radial growth response increased during the following 10 years. We can assume that fire eliminated the crown and the understory, drying out superficial soil and modifying soil microfauna, thus producing on pine radial growth similar consequences than that caused by a severe drought.

\section{Conclusions}

Differences in Salzmann pine radial growth response to climate variations are pronounced between the three sites of the study: at the southernmost site (CO), radial growth is positively correlated with spring precipitations, whereas in the two northern sites (GT, SG), it is correlated with temperatures. Such differences reflect a combined effect of regional climate characteristics and soil types on radial growth. As a low but significant genetic differentiation has been found between the Salzmann pine populations of the Pyrenees (CO) and the Massif Central (GT, SG) (Fady et al. 2010), differences in radial growth could also be due to local adaptation although our study does not make it possible to disentangle its effects from that of widespread phenotypic plasticity.

Moving response functions indicate radial growth/climate relationships evolving over time throughout the second half of the twentieth century. Particularly, synchronous patterns at all sites highlight an increasingly negative correlation between radial growth and July temperatures. In a context of climate change where summer temperatures are predicted to increase, Salzmann pine is likely to experience a reduction in radial growth during the twenty-first century.

Acknowledgments We gratefully acknowledge Norbert Turion, Olivier Gilg, and Franck Rei (INRA UEFM, Avignon) for the field work and the "Programme global de conservation des populations françaises de pin de Salzmann" funded by the French National Forest Service (ONF) for the financial support. We also thank Mélanie Saulnier and Élodie Brisset (UMR IMBE, Aix-Marseille University) for the technical advice.

\section{References}

Andreu L, Gutiérez E, Macias M, Ribas M, Bosch O, Camarero J (2007) Climate increases regional tree-growth variability in Iberian pine forests. Glob Chang Biol 13:804-815
Biondi F, Waikul K (2004) DENDROCLIM2002: a C++ program for statistical calibration of climate signals in tree-ring chronologies. Comput Geosci 30:303-311

Bogino S, Bravo F (2008) Growth response of Pinus pinaster Ait. to climatic variables in central Spanish forests. Ann For Sci 65:506

Calas M (1900) Le Pin laricio de Salzmann. Imprimerie nationale, Paris, p 50

Campelo F, Nabais C, Freitas H, Gutiérez E (2007) Climatic significance of tree-ring width and intra-annual density fluctuations in Pinus pinea from a dry Mediterranean area in Portugal. Ann For Sci 64:229-238

Campelo F, Nabais C, Garcia-González I, Cherubini P, Gutiérez E, Freitas H (2009) Dendrochronology of Quercus ilex L. and its potential use for climate reconstruction in the Mediterranean region. Can J For Res 39:2486-2493

Costa M, Morla C, Sainz H (1997) Los bosques ibéricos: una interpretación geobotánica. (ed). Planeta, Barcelona. pp 572

Dereuddre J, Gazeau C (1992) Les végétaux et les très basses températures. In: Côme D (ed) Les végétaux et le froid. Hermann, Paris, pp 107-175

Fady B, Brahic P, Cambon D, Gilg O, Rei F, Roig A, Royer J, Thévenet J, Turion N (2010) Valoriser et conserver le Pin de Salzmann en France. For Méditerr 31:3-14

Fritts HC (1976) Tree rings and climate. Academic, London, p 567

Génova M, Fernández A (1999) Tree rings and climate of Pinus nigra subsp. salzmannii in central Spain. Dendrochronologia 16-17:75-85

Génova M, Martinez-Morillas D (2002) Estudio dendroecologico de Pinus nigra en Checa (Guadalajara). Ecologia 16:83-95

Guiot J (1991) Research report, the bootstrapped response function. Tree-Ring Bull 51:39-41

Guiot J, Gœury C (1996) PPPBASE, a software for statistical analysis of paleoecological and paleoclimatological data. Dendrochronologia 14:295-300

Guiot J, Nicault A (2010) Méthodes de dendroclimatologie à l'échelle continentales: fonctions de réponse et fonctions de transfert. In: Payette S, Filion L (eds) La dendroécologie: principes, méthodes et applications. Presses de l'Université de Laval, Laval, pp 229-253

Holmes RL (1983) Computer-assisted quality control in tree-ring dating and measurement. Tree-Ring Bull 43:69-78

Houghton J (2011) Le réchauffement climatique: état des lieux complet. De Boeck, Bruxelle, p 495

Lebourgeois F (2000) Climatic signals in earlywood, latewood and total ring width of Corsican pine from western France. Ann For Sci 57:155-164

Linares JC, Tiscar PA (2010) Climate change impacts and vulnerability of the southern populations of Pinus nigra subsp. salzmannii. Tree Physiol 30:795-806

Martin-Benito D, Del Rio M, Cañellas I (2010) Black pine (Pinus nigra Arn.) growth divergence along a latitudinal gradient in Western Mediterranean Mountains. Ann For Sci 67:401

Mitchell TD, Hulme M, New M (2002) Climate data for political areas. Area 34:109-112

Quézel P, Barbéro M (1988) Signification phytoécologique et phytosociologique des peuplements naturels de Pin de Salzmann en France. Ecol Mediterr 14:41-63

Vernet J-L (2006) History of the Pinus sylvestris and Pinus nigra ssp. salzmanni forest in the sub-Mediterranean mountains (Grands Causses, Saint-Guilhem-le-Desert, southern Massif Central, France) based on charcoal from limestone and dolomitic deposits. Veget Hist Archaeobot 16:23-42

Vernet JL, Meter A, Zéraïa L (2005) Premières datations de feux holocènes dans les monts de Saint-Guilhem-le-Désert (Hérault, France), contribution à l'histoire de la forêt relique de Pinus nigra Arnold ssp. salzmanni (Dun.) Franco. Géosciences 337:533-537

Wieser G (1997) Carbon dioxide gas exchange of cembran pine (Pinus cembra) at the alpine timberline during winter. Tree Physiol 17:473-477 